\title{
A Comparative Study between the Effect of Pandan Wangi Leaves Boiled Water with Medication Therapy on the Blood Pressure Changes of Hypertension Patients
}

Wahyuningsih Safitri* ${ }^{*}$, Yoanita Putri, Ririn Afrian Sulistyawati, Febriana Sartika Sari ${ }^{\text {D }}$, Maria Wisnu Kanita, Yunita Wulandari, Wahyu Rima Agustin ,S Dwi Sulisetyawati, Meri Oktariani

Department of Nursing, Faculty of Health Sciences, Universitas Kusuma Husada Surakarta, Kota Surakarta, Jawa Tengah, Indonesia

Abstract

Edited by: Mirko Spirosk Citation: Safitri W, Putri Y, Sulistyawati RA, Sari FS, Kanita MW, Wulandari Y, Agustin WR, Sulisetyawati SD Oktariani M. A Comparative Study between the Effect of Pandan Wangi Leaves Bolled Water with Medication Therapy on the Blood Pressure Changes of Hypertension 9(G):317-320. https://doi.org/10.3889/oamjms.2021.735 Keywords: Blood pressure; Hypertension; *Correspondence: Wahyuningsin Safitri, Department of
Nursing, Faculty of Health Sciences Universitas Kusuma Nursing, Faculty of Health Sciencesakarta, Jawa Tengah,
Husada Surakarta, Kota Surakat Indonesia. E-mail: wahyuningsihsafitri@gmail.com Received: $17-\mathrm{Sep}-202$ Revised: 17-Oct-2021
Accepted: 19-Nov-2021 Revised: 17-Oct-2021
Accepted: 19-Nov-2021 Ririn Afrian Sulistyawati, Febriana Sartia Maria Wisnu Kanita, Yunita Wulandari,

Funding: The research had financial support from Universitas Kusuma Husada Surakarta Competing Interests: The authors have declared that no
competing interests exist Competing Interests: The authors have declared that no
competing interests exist under the terms of the Creative Commons Attribution-

\begin{abstract}
BACKGROUND: Hypertension is an asymptomatic condition. There is abnormally high pressure in the arteries which increases the risk of stroke, aneurysm, heart attack, myocardial infarction, and kidney damage. Management of hypertension can use pharmacological and non-pharmacological techniques. One of the non-pharmacologica therapies is using boiled water from Pandan Wangi leaves.

AIM: The study aimed to compare between the effects of Pandan Wangi boiled water with medication therapy on the blood pressure changes in hypertension patients in the working area of Public Health Center, Karanganyar.

METHODS: This study used a quasi-experimental research design with a pre-test and post-test with a nonequivalent group control design. The sampling technique adopted a purposive sampling technique consisted of 120 respondents. Data were analyzed using the Wilcoxon test and the Mann-Whitney test.

RESULTS: The Wilcoxon test results in the treatment and control groups showed the same results. Systolic blood pressure obtained $p=0.004(p<0.05)$ and diastolic blood pressure obtained $p=0.002(p<0.05)$. Both the treatment group and the control group affect the blood pressure changes in hypertension patients. The Mann-Whitney test results obtained systolic blood pressure with $p=0.148(p>0.05)$ and diastolic with $p=1.000(p>0.05)$.

CONCLUSION: The results emphasized Pandan Wangi boiled water can reduce the blood pressure, and there is no difference in the effectiveness of Pandan Wangi boiled water and medication therapy on the blood pressure of hypertension patients in the working area of Public Health Center, Karanganyar.
\end{abstract}

\section{Introduction}

Hypertension is a condition in which a person has increased blood pressure above normal, increasing morbidity and mortality [1]. Blood vessel pressure in patients with hypertension has increased chronically. It appears because the heart pumps blood to meet the body's oxygen and nutritional needs and works harder. Untreated hypertension could interfere with the function of other organs, especially vital organs such as the heart and kidneys [2].

Hypertension sufferers do not feel any symptoms and experience an improvement in blood pressure directly. It raises the risk of various diseases in the body, such as kidney damage, stroke, and heart attack [3]. Besides that, it can cause blindness [4].

There have been many methods obtained to relieve hypertension, both pharmacological and nonpharmacological therapy. Pharmacological therapy consists of administering drugs that are diuretic, sympathetic, beta-blocker, and vasodilator by paying attention to the site, mechanism of action, and level of compliance [5]. Non-pharmacological therapy includes traditional plants, reflexology, hypnotherapy, and others. Non-pharmacological treatment is a form of treatment without drugs, for example, herbal drinks [1]. One of the non-pharmacological therapies is Pandan Wangi leaves.

Leaf's extract of Pandan Wangi is beneficial for natural antioxidants with a justly high antioxidant activation of $66.82 \%$. One of the boiled water extract ingredients of Pandan Wangi leaves (EADPW) is flavonoids [6]. Flavonoids work by inhibiting angiotensin converting enzyme (ACE). Therefore, angiotensin II does not accumulate in the blood vessels affects a reduction in blood pressure. Quercetin-type flavonoids work directly on the smooth muscle of arteries causing vasodilation [7].

Putriana [8] stated that leaf decoction affected blood pressure in mice. Pandan Wangi leaves do not have any harmful side effects on humans, although it was conducted on mice. The study conducted by Khotijah et al. [9] and Citerawati et al. [10] inferred that 
Pandan Wangi leaves were an effect of lowering blood sugar in people with type 2 diabetes.

Pandan Wangi leaves have many benefits and have no harmful side effects on humans but there is still little research, especially on blood pressure in humans. Therefore, researchers are interested in researching the comparison between the effect of providing Pandan Wangi leaves boiled water with medication therapy on blood pressure changes in hypertension patients.

\section{Ethics approval}

This study was approved by the Health Research Ethics Committee, University of Kusuma Husada Surakarta (37/UKH.L.02/EC/VII/2020). Before collecting data, each respondent had signed informed consent, and was informed about their voluntary participation, their identities anonymous, and no personally identifiable information is taken to ensure confidentiality. The data are deleted permanently after data collection is completed.

\section{Methods}

\section{Study design}

This research was quantitative research with a quasi-experimental research design with a pre- and post-test with a non-equivalent group control design.

\section{Sample/participants}

The study was conducted in Karanganyar area from August 6 to August 14, 2020. The population of this study was hypertension patients with 120 people. This study used total sampling, in hence, the amounted of sample was 120 respondents who were divided into two groups, namely, the intervention and control group.

\section{Instrument}

This study was used sphygmomanometer and stethoscope to measured blood pressure of respondents in before and after intervention, and used observation paper.

\section{Intervention}

The intervention group received treatment in the form of giving Pandan Wangi leaves boiled water for 7 days with one time per day. Producing Pandan Wangi leaves boiled water is as follows: (1) Washing $6 \mathrm{~g}$ of Pandan Wangi leaves in running water and cutting them into small pieces. (2) Boil Pandan Wangi leaves with $400 \mathrm{ml}$ water at $100^{\circ} \mathrm{C}$ for $\pm 20 \mathrm{~min}$. (3) Strain and distribute the dregs until the leftover $200 \mathrm{ml}$ of the boiling water. And (4) boiled water of Pandan leaves was delivered to the respondents. The control group was given standard treatment, mainly medication treatment.

\section{Data collection}

This study was conducted with 2 times of data collection, namely, pre-test and post-test. The pretest was carried out before the treatment was given, namely, by checking the respondent's blood pressure in the intervention and control groups, and the post-test was carried out after 7 days of treatment.

\section{Data analysis}

Data in this study have been analyzed using the SPSS program version 24.0 (IBM Corp. Armonk, New York, USA), and presented with tables. Categorical data are presented with frequency and percentage. Numerical data are presented with mean, median, and standard deviation (SD). Differences of blood pressure between the two groups were analyzed using the Mann-Whitney. Differences of blood pressure before and after intervention in each group were measured using the Wilcoxon Signedrank test. The normality test in this study used Kolmogorov-Smirnov.

\section{Results}

Table 1 shows the demographic characteristic of respondents. The most of the respondents were in the age range of 40-80 years, namely, in the intervention group $58 \%$ and the control group $67 \%$. Table 1 also shows that the most of the respondents were women, namely, in the intervention group $67 \%$ and the control group $75 \%$.

\begin{tabular}{|c|c|c|c|c|}
\hline \multirow[t]{2}{*}{ Variable } & \multicolumn{2}{|c|}{ Intervention group $(\mathrm{n}=60)$} & \multicolumn{2}{|c|}{ Control group $(n=60)$} \\
\hline & Frequency & $(\%)$ & Frequency & $(\%)$ \\
\hline \multicolumn{5}{|l|}{ Age } \\
\hline $40-60$ years & 25 & 42 & 20 & 33 \\
\hline $61-80$ years & 35 & 58 & 40 & 67 \\
\hline \multicolumn{5}{|l|}{ Gender } \\
\hline Male & 20 & 33 & 15 & 25 \\
\hline Female & 40 & 67 & 45 & 75 \\
\hline
\end{tabular}

The results show that there was no difference in blood pressure between the intervention and control groups with $p=0.148(p<0.05)$ in systole and $p=1,000$ $(p<0.05)$ in diastole (Table 2$)$. The intervention group received boiled water from Wangi Pandan leaves, and the control group used standard therapy (medication). Table 3 shows that there was a decrease in systolic 
and diastolic blood pressure between before and after therapy in both groups, and that there was the difference in blood pressure before and after treatment in the intervention and control groups.

Table 2. Blood pressure difference between intervention and control group $(n=120)$

\begin{tabular}{lll}
\hline Blood Pressure & Group & p-value \\
\hline Systole & Intervention & 0.148 \\
Diastole & $\begin{array}{l}\text { Control } \\
\text { Intervention } \\
\text { Control }\end{array}$ & 1.000 \\
\hline Analysis used Mann-Whitney test & &
\end{tabular}

\section{Discussion}

The results of this study indicate that most respondents were in the age range of 40-80 years, this is in line with research by Anggara and Prayitno [11], which stated that hypertension usually affects individuals over the age of 40 years. Age over 40 results in an increase in blood pressure as blood continues to pump, indicating that the blood vessels are dilated. Jannah et al. [12] stated that the accumulation of collagen substances in the muscle layer and thickening of the arterial walls resulted in narrowing and stiffness of blood vessels. Another condition that supports the incidence of hypertension in the elderly is telomere shortening. Telomere shortening is progressive with aging-related diseases such as cardiovascular disease [13].

Table 3: Blood pressure of pre- and post-intervention

\begin{tabular}{|c|c|c|c|c|}
\hline $\begin{array}{l}\text { Blood } \\
\text { Pressure }\end{array}$ & Group & Mean \pm SD & Median (minimum-maximum) & p-value \\
\hline \multirow[t]{6}{*}{ Intervention } & Systole & & & $0.004^{*}$ \\
\hline & Pre-test & $159 \pm 56.76$ & $160(150-170)$ & \\
\hline & Post-test & $132 \pm 42.16$ & $130(130-140)$ & \\
\hline & Diastole & & & $0.002^{*}$ \\
\hline & Pre-test & $91 \pm 31.62$ & $90(90-100)$ & \\
\hline & Post-test & $81 \pm 31.62$ & $80(80-90)$ & \\
\hline \multirow[t]{6}{*}{ Control } & Systole & & & $0.004^{*}$ \\
\hline & Pre-test & $152 \pm 91.89$ & $150(140-170)$ & \\
\hline & Post-test & $136 \pm 69.92$ & $135(130-150)$ & \\
\hline & Diastole & & & $0.002^{*}$ \\
\hline & Pre-test & $91 \pm 31.62$ & $90(90-100)$ & \\
\hline & Post-test & $81 \pm 31.62$ & $80(80-90)$ & \\
\hline
\end{tabular}

This study shows that most respondents were women, this is in line with research conducted by Ansar et al. [14] which showed that the majority of respondents with hypertension were women. The results of research conducted by Kusumawaty et al. [15] stated that there was a close relationship between gender and hypertension.

According to the Lintasari [16], hypertension in young women is considered lower, when the age of 45 years and over, they must start to be more alert to the threat of this disease because when women begin to experience menopause, the prevalence of hypertension is actually higher. Women who have not menopause are protected by the hormone estrogen which plays a role in increasing levels of high density lipoprotein (HDL). Low HDL cholesterol levels and high LDL cholesterol (low density lipoprotein) affect the atherosclerosis process and result in high blood pressure [17], [18].

Therapy that can be used to reduce blood pressure is to use pharmacological therapy, one of which is amlodipine. According to the Muchtar et al. [19], amlodipine is an antihypertensive drug that has a pharmacological effect as an antihypertensive agent with a calcium channel blocker (CCB) mechanism of action. Amlodipine is able to the lower blood pressure by inhibiting calcium ions from entering the vasculature of cardiac and smooth muscle [20].

Besides, in this study shows that Pandan Wangi leaves can reduce the blood pressure. Pandan Wangi leaves contain flavonoids which have a hypotensive effect with the mechanism of inhibiting ACE activity and diuretics. Flavonoids can inhibit ACE which is known to play a role in the formation of angiotensin II which is one of the causes of hypertension. Angiotensin II causes constriction of blood vessels so that blood pressure can increase, ACE inhibitors cause dilation of blood vessels so that blood flow to the heart is more and lowers blood pressure [12].

In addition, the flavonoid quercetin in Pandan Wangi leaves functions as an antioxidant in lowering blood pressure. Quercetin is a biologically active substance in the flavonoid group that produces solid antioxidant activity and inhibits the oxidation process by neutralizing free radicals [21].

Pandan Wangi leaves are safe for consumption for patients, this is in line with Khotijah [9] research that the effect of boiled water from Pandan Wangi leaves on random blood sugar in type $2 \mathrm{DM}$ is not dangerous for human consumption with $6 \mathrm{~g}$ of Pandan Wangi leaves boiled in $400 \mathrm{ml}$ of distilled water up to $200 \mathrm{ml}$ per drink. Pandan Wangi leaf water extract provides antioxidant activation of $66.82 \%$. The content of fragrant Pandan leaf extract (EADPW) is flavonoid [6].

\section{practice}

\section{Implication for nursing management and}

The boiled water of Pandan Wangi leaves can lower the blood pressure of people with hypertension and is safe for consumption. Therefore, it can be recommended to patients, as an alternative therapy in lowering blood pressure.

\section{Limitation of the study and future recommendations}

This study uses a quasi-experimental method, so there are still many biases found and the sample selection is not random. In addition, the measurement of blood pressure was carried out at the end of the therapy, namely, on the $7^{\text {th }}$ day, so it could not show that the length of time the therapy was effective, so for further research, random sampling and time series design were needed. 


\section{Conclusion}

Pandan Wangi leaves boiled water can reduce systolic and diastolic blood pressure, and there was no difference in the effectiveness of Pandan Wangi leaves boiled water and drug therapy on reducing systolic and diastolic blood pressure in hypertension patients.

\section{References}

1. Triyanto E. Integrated Nursing Services for Hypertensive Patients. Yogyakarta: Graha IImu; 2014.

2. Indonesian Ministry of Health. Basic Health Research Results Report (RISKESDAS). National 2013. Indonesia: Indonesian Ministry of Health; 2013. Available from: https://www.litbang. kemkes.go.id/laporan-riset-kesehatan-dasar-riskesdas [Last accessed on 2019 Oct 08].

3. Sutanto S. Block (Prevent and Guard) Modern Disease. Yogyakarta: CV; 2010.

4. Dendup T, Tshering P, Dorji T. Risk factors associated with hypertension in Bhutan: Findings from the national health survey. J Health Res. 2020;35(6):540-52.

5. Handayani H, Kusmiyati K, Sumatywati N. The effect of treatment of tomato (lycopersicum grandifolium) on blood pressure reduction in the elderly with hypertension in PSTW "PUSPAKARMA" Mataram. J Biol Trop. 2013;13(1):102-8.

6. Prameswari OM, Widjanarko SB. The effect of water extract of pandan wangi leaf to decrease blood glucose levels and pancreas histopathology at diabetes mellitus rats. J Food Agroindustry. 2014;2(2):16-27.

7. Athiroh A, Nour, Permatasari N. Mechanism of Tea Mistletoe Action on Blood Vessels. Brawijaya Med J. 2012;27(1):1-7.

8. Putriana Y. The Effect of Decoction of Pandan Wangi Leaves (Pandanus amaryllifolius Roxb.) on Reducing High Blood Pressure Male White Rats (Rattus norvegicus L.) and Its Utilization as a Popular Scientific Work. Jember: University of Jember; 2015.

9. Khotijah ES, Adi GS, Ekacahyaningtyas M. The Effect of Giving Pandan Leaves Stew toward Random Blood Sugar Level of Type 2 Diabetes Mellitus Patients in The Working Area of Gemolong Public Health Center. Indonesia: Health Science School of Kusuma Husada Surakarta; 2019.

10. Citerawati YW, Hapsari RA, Konoralma GM. The Effect of Avocado Seed and Pandan Leaves Booked Water on
Blood Sugar Levels of Diabetes Mellitus Type II Patients in Panarung and Bukit Hindu Public Health Center. J Heal Forum. 2018;8(1):52-8.

11. Anggara F, Prayitno N. Diabetic retinopathy. factors assoc with blood press telaga Murni Heal center, West Cikarang 2012. Heal Sci J. 2013;5(1):575-98.

12. Jannah $M$, Noorjannah $N$, Adelia N. Effectiveness test of pandan leaf extract (Pandanus amaryllifolius Roxb.) as anti hypertension. Heal Dyn. 2018;3(1):91-9.

13. Zgheib NK, Sleiman F, Nasreddine L, Nasrallah M, Nakhoul N Isma'eel $\mathrm{H}$, et al. Short telomere length is associated with aging, central obesity, poor sleep and hypertension in lebanese individuals. Aging Dis. 2018;9(1):77-89. https://doi. org/10.14336/AD.2017.0310 PMid:29392083

14. Ansar J, Dwinata IM. Determinants of hypertension incidence in posbindu visitors in the work area of the Ballaparang Health Center Makassar city. Natl J Heal Sci. 2019;1(3):28-35.

15. Kusumawaty J, Hidayat N, Ginanjar E. Factors related events sex with hypertension in elderly work area health district lakbok ciamis. Mutiara Med J. 2016;16(2):46-51.

16. Lintansari. Effect of Giving Tomatoes (Lycopersicon Lycopersicum) on Changes in Blood Pressure in Hypertensive Patients at UPTD Bojongsari Public Health Center, Purbalingga Regency. Indonesia: University of Muhammadiyah Purwokerto; 2012.

17. Armstrong SM, Sugiyama MG, Fung KY, Gao Y, Wang C, Levy AS, et al. A novel assay uncovers an unexpected role for SR-BI in LDL transcytosis. Cardiovasc Res. 2015;108(2):268-77. https://doi.org/10.1093/cvr/cvv218 PMid:26334034

18. Riyadina W, Kodim N, Bantas K, Trihandini I, Sartika RA, Martha $\mathrm{E}$, et al. Triglycerides as a prognosis factor for uncontrolled hypertension in post-menopausal women in Bogor city, 2014. Bul Heal Res. 2017;45(2):89-96.

19. Muchtar NR, Tjitrosantoso H, Bodhi W. Study on the use of antihypertensive drugs in patients with chronic kidney failure undergoing treatment at the Prof. Hospital. Dr. R. D. Kandou Manado Period July 2013-June 2014. Pharmacon. 2015;4(3):22-8.

20. Lakshmi K, Lakshmi S. Simultaneous analysis of losartan potassium, amlodipine besylate, and hydrochlorothiazide in bulk and in tablets by high-performance thin layer chromatography with UV-absorption densitometry. J Anal Methods Chem. 2012;2012:108281. https://doi.org/10.1155/2012/108281 PMid:22567550

21. Sofalina D. The Effect of Pandandus (Pandanus amaryllifolius) Leave Extract on Reducing Blood Glucose Levels Induced by Streptozotocin Mice. Indonesia: University of Airlangga; 2013. 